\title{
Annonces / Announcements
}

\section{Le dialogique}

Le dialogique, voilà le sujet d'un colloque international sur les formes philosophiques, littéraires, linguistiques et cognitives du dialogue. Ce colloque aura lieu les 15 et 16 septembre 1994 à l'Université du Maine, Le Mans, France. Pour de plus amplesrenseignements, veuillez écrire à Antoine Compagnon, Département de français, Université du Maine, B.P. 535, 72017 Le Mans Cedex, France.

\section{Food and Drink in the Middle Ages and Early Renaissance}

Food and Drink will be the focus of attention at the 21st Annual ACTA Conference to be held on 22-23 April 1994 at the State University of New York, Binghamton. For more information, please write to: Prof. Mary Jo Arn, Department of English, Bakeless Center for Humanities, Bloomsburg University, Bloomsburg, Pennsylvania 17815, USA.

\section{William Tyndale}

The Catholic University of America nd the Folger Institute present a conference entitled William Tyndale: Church, State \& Word. The conference will be held on 14-17 July 1994 at the Catholic University. Inquiries to Prof. Anne M. O'Donnell, English Department, Catholic University of America, Washington, DC 20064, USA.

\section{Canadian Society for Renaissance Studies}

The annual conference of the CSRS will be held on 5-7 June 1994 at the University of Calgary. For more information, please contact Prof. Ronald Bond, Dean of Humanities, University of Calgary, 2500 University Drive N.W., Calgary, Alberta T2N 1N4.

\section{Société Canadienne d'Études de la Renaissance}

Le congrès annuel de la SCER aura lieu du 5 au 7 juin 1994 à l'Université de Calgary. Pour de plus amples renseignements, prière de communiquer avec le 
Prof. Ronald Bond, Dean of Humanities, University of Calgary, 2500 University Drive N.W., Calgary, Alberta T2N 1 N4.

\section{Thomas More Symposium}

The Fifth International Thomas More Symposium will be held 20-27 May 1995 in Mainz, Germany. For information, please write to: Prof. Hermann Boventer, Thomas-Morus-Gessellschaft, Hubertushöhe 9, Bendberg, 51429 BergischGladbach, Germany.

\section{Littérature chevaleresque}

Sagesse, démesure et folie dans la littérature chevaleresque, le poème héroïque et l'épopée en Europe à la Renaissance, voilà le sujet d'un prochain colloque du 21 au 23 octobre 1994 à l'Université de Saint-Étienne. Veuillez écrire à l'Institut Claude Longeon, 35, rue du Onze Novembre, 42023 Saint-Étienne Cedex 2, France.

\section{Montaigne et $M^{\text {lle }}$ de Gournay}

Pour marquer l'anniversaire de l'édition de 1595 des Essais de Montaigne, la Division de liitérature française du $\mathrm{XVI}^{\mathrm{e}}$ siècle de la MLA organise une séance spéciale consacrée à $\mathrm{M}^{\text {lle }}$ de Gournay et l'édition de 1595. Le congrès de la MLA aura lieu à Chicago en 1995. Pour de plus amples renseignements, veuillez écrire à Ellen S. Ginsberg, Department of Modern Languages, Catholic University of America, Washington, D.C. 20064, USA.

\section{Early Modern Culture, 1450-1850}

This is the topic of the Second Annual Meeting of the Group for early Modern Culural Studies at the University of Rochester. The call for papers suggests the following areas, among others: Africa and African Diaspora, Colonialism and Occidentalism, Pornography, Disease, Death, Everyday Life, Slavery, Commodities and Fetishism, Travel and Tourism, Resistance and Rebellion, Sexuality, Musical Genders. For more information, please write to Prof. Thomas DiPiero, Department of Modern Languages and Cultures, 303 Gavett Hall, University of Rochester, Rochester, New York 14627, USA. 